\title{
Treatment with the Mycoparasite Pythium oligandrum Triggers Induction of Defense-Related Reactions in Tomato Roots When Challenged with Fusarium oxysporum f. sp. radicis-lycopersici
}

\author{
Nicole Benhamou, Patrice Rey, Mohamed Chérif, John Hockenhull, and Yves Tirilly
}

First author: Recherche en Sciences de la vie et de la santé, Pavillon Charles-Eugène Marchand, Université Laval, Sainte-Foy, Québec, Canada G1K 7P4; second, third, and fifth authors: ESMISAB, Laboratoire de Microbiologie et Biochimie, Université de Bretagne Occidentale, Technopole Brest-Iroise, 29280, Plouzané, France; fourth author: Department of Plant Biology, The Royal Veterinary and Agricultural University, 40 Thorvaldsensvej, DK-1871 Fredriksberg, Copenhagen, Denmark.

Accepted for publication 18 October 1996.

\begin{abstract}
Benhamou, N., Rey, P., Chérif, M., Hockenhull, J., and Tirilly, Y. 1997. Treatment with the mycoparasite Pythium oligandrum triggers induction of defense-related reactions in tomato roots when challenged with Fusarium oxysporum f. sp. radicis-lycopersici. Phytopathology 87:108-122.

The influence exerted by the mycoparasite Pythium oligandrum in triggering plant defense reactions was investigated using an experimental system in which tomato plants were infected with the crown and root rot pathogen Fusarium oxysporum f. sp. radicis-lycopersici. To assess the antagonistic potential of $P$. oligandrum against $F$. oxysporum f. sp. radicis-lycopersici, the interaction between the two fungi was studied by scanning and transmission electron microscopy (SEM and TEM, respectively). SEM investigations of the interaction region between the fungi demonstrated that collapse and loss of turgor of $F$. oxysporum f. sp. radicis-lycopersici hyphae began soon after close contact was established with $P$. oligandrum. Ultrastructural observations confirmed that intimate contact between hyphae of $P$. oligandrum and cells of the pathogen resulted in a series of disturbances, including generalized disorganization of the host cytoplasm, retraction of the plasmalemma, and, finally, complete loss of the protoplasm. Cytochemical labeling of chitin with wheat germ agglutinin (WGA)/ovomucoid-gold complex showed that, except in the area of hyphal penetration, the chitin component of the host cell walls was structurally preserved at a time when the host cytoplasm had undergone complete disorganization. Interestingly, the same antagonistic process was observed in planta. The specific labeling patterns obtained with the exoglucanase-gold and WGA-ovomucoid-gold complexes confirmed that

inoculated tomato roots revealed that the fungus was able to colonize root tissues without inducing extensive cell damage. However, there was a novel finding concerning the structural alteration of the invading hyphae, evidenced by the frequent occurrence of empty fungal shells in root tissues. Pythium ingress in root tissues was associated with host metabolic changes, culminating in the elaboration of structural barriers at sites of potential fungal penetration. Striking differences in the extent of $F$. oxysporum f. sp. radicis-lycopersici colonization were observed between $P$. oligandrum-inoculated and control tomato plants. In control roots, the pathogen multiplied abundantly through much of the tissues, whereas in $P$. oligandrum-colonized roots pathogen growth was restricted to the outermost root tissues. This restricted pattern of pathogen colonization was accompanied by deposition of newly formed barriers beyond the infection sites. These host reactions appeared to be amplified compared to those seen in nonchallenged $P$. oligandrum-infected plants. Most hyphae of the pathogen that penetrated the epidermis exhibited considerable changes. Wall appositions contained large amounts of callose, in addition to be infiltrated with phenolic compounds. The labeling pattern obtained with gold-complexed laccase showed that phenolics were widely distributed in Fusarium-challenged $P$. oligandrum-inoculated tomato roots. Such compounds accumulated in the host cell walls and intercellular spaces. The wall-bound chitin component in Fusarium hyphae colonizing P. oligandrum-inoculated roots was preserved at a time when hyphae had undergone substantial degradation. These observations provide the first convincing evidence that $P$. oligandrum has the potential to induce plant defense reactions in addition to acting as a mycoparasite.
\end{abstract} $P$. oligandrum successfully penetrated invading cells of the pathogen without causing substantial cell wall alterations, shown by the intense labeling of chitin. Cytological investigations of samples from P. oligandrum-
Additional keywords: antagonism, gold cytochemistry, plant induced resistance.
Greenhouse production of tomatoes is seriously hampered by $\mathrm{Fu}-$ sarium crown and root rot, which causes widespread, heavy economic losses on plants grown in sterilized soils (24). This disease also is devastating in hydroponic production systems, mainly because of the ease with which the pathogen can spread from one plant to another. The speed and extent to which Fusarium oxysporum f. sp. radicis-lycopersici Jarvis \& Shoemaker can disseminate and infect tomato plants may explain why natural disease resistance is seldom monitored. Although some tomato cultivars with single dominant genes for resistance have been developed, control of Fusarium wilt in tomato is mainly restricted to eliminating the pathogen in soil by steaming or fumigating with chemicals and planting pathogen-free stocks (41). However, complete

Corresponding author: N. Benhamou; E-mail address: nben@ rsvs.ulaval.ca

Publication no. P-1996-1205-02R

(C) 1997 The American Phytopathological Society eradication of the fungus from soil has never been achieved, due in part to the appearance of fungicide-resistant strains in the pathogen population. This problem is compounded by the fact that pesticide applications on greenhouse crops have become strongly regulated. The difficulties in controlling Fusarium crown and root rot of tomato have prompted scientists to search for biological alternatives that are efficient, reliable, and safe for the environment $(9,25,43)$. Several biocontrol strategies have been proposed for controlling root pathogens, but practical applications are still limited, largely because of the lack of unequivocal answers to key questions, including the relationship the biocontrol agent may establish with the plant and the exact mechanisms by which it may directly influence the pathogen or indirectly influence the plant by inducing metabolic changes (11).

Among the antagonists that have shown satisfactory degrees of control of $F$. oxysporum f. sp. radicis-lycopersici, Trichoderma spp. (17) and fluorescent pseudomonads (29) have been reported to reduce disease incidence by inhibiting pathogen growth and de- 
velopment in the rhizosphere (33). Another mycoparasite receiving considerable attention as a potential biocontrol agent of a number of soilborne plant pathogens is Pythium oligandrum Dreschsler $(10,13,35)$. Since the initial mention that $P$. oligandrum could be a secondary invader of diseased plant root tissues in addition to acting as a hyperparasite on primary pathogens (18), the antagonistic activity of this oomycete fungus has been abundantly documented (34). Understandably, the mechanisms by which P. oligandrum controls pathogenic populations in the rhizosphere have been studied intensively. Several lines of evidence from in vitro studies have shown that direct mycoparasitism is involved in the antagonistic process (34). Recent progress in the use of scanning electron microscopy (SEM) (36) and video microscopy (32) has led to the consideration that, in most cases, P. oligandrum establishes close contact with the host mycelium or even coils around it prior to initiating penetration by partially degrading the host cell wall. Although mycoparasitism currently is considered the primary mechanism involved in biological control by $P$. oligandrum, the possibility that antibiosis (13) and competition for nutrients in the rhizosphere may play an important role in the microbial interactions has been raised (20).

In spite of the increasing amount of research devoted to the antimicrobial activity of $P$. oligandrum in vitro $(10,13)$, knowledge of the exact mechanisms responsible for the observed reduction of disease incidence after soil treatment with $P$. oligandrum propagules is incomplete. Although there is no doubt that reduction of pathogen population density through a direct antimicrobial activity exerted by the antagonist is responsible, at least partially, for the enhanced plant protection described by several authors, the possibility that $P$. oligandrum also may trigger indirect effects by stimulating the plant defense system has not been investigated. Considering that increased plant growth response has often been observed after treatment of seeds $(36,45)$ and young plants (J. Hockenhull, unpublished data), it is surprising that little attention has been paid to the cytological and physiological changes occurring at the onset of plant colonization by the mycopathogen. In a recent biochemical study, Kratka et al. (30) reported that stimulation of phosphorus uptake in $P$. oligandrum-inoculated cucumber plants could explain the observed growth promotion. Although not investigated in their study, the authors suggested that changes in the metabolism of these plants could be associated with the elaboration of plant defense reactions. At present, the situation is not clearly defined, and the possibility that plant induced resistance may account for the recorded reduction in disease incidence after treatments with $P$. oligandrum deserves to be studied more fully. To function efficiently as a biological inducer of plant defense responses, some attempt at invasion of root tissues by $P$. oligandrum is anticipated.

Although evidence is now accumulating from biocontrol (45) and other experiments (30) that suggests $P$. oligandrum may be slightly damaging to healthy plant roots, the effect appears to be transient and reversible. At this point, very little information is available on several key questions, including (i) what is the pattern of root colonization by $P$. oligandrum and to what extent does the mycoparasite actually invade plant roots and establish itself within the host root tissues; (ii) does $P$. oligandrum display antimicrobial activity in vivo; and (iii) is $P$. oligandrum capable of provoking a plant to defend itself against pathogenic fungi that may have escaped the first line of defense in the rhizosphere? Elucidating the cytological events associated with the development of nonpathogenic organisms in plant tissues is an essential complement to biochemical investigations and is of particular relevance when studying their mode of action in relation to possible pathogen restriction in planta.

In an attempt to address these important questions, the objectives of the current research were (i) to determine the pattern of tomato root colonization by $P$. oligandrum; (ii) to delineate the biological events associated with the tomato- $P$. oligandrum interac- tion; and (iii) to investigate ultrastructurally the outcome of the tomato- $F$. oxysporum $\mathrm{f}$. sp. radicis-lycopersici interaction in the presence of $P$. oligandrum. In this report, we present the first conclusive evidence that $P$. oligandrum penetrates and grows in tomato root tissues in addition to exhibiting antimicrobial activity in planta and sensitizing the plant to respond rapidly and efficiently to F. oxysporum f. sp. radicis-lycopersici attack.

\section{MATERIALS AND METHODS}

Plant material. Tomato seeds (Lycopersicon esculentum Mill. 'Prisca') susceptible to $F$. oxysporum f. sp. radicis-lycopersici were sterilized by immersion in $70 \%$ ( $\mathrm{vol} / \mathrm{vol})$ ethanol for $7 \mathrm{~min}$, thoroughly rinsed, and soaked overnight in sterile water. Seeds were sown in peat at a density of 10 seeds per flat. Plants were propagated in a greenhouse at 22 to $24^{\circ} \mathrm{C}$ with a 14-h photoperiod and were fertilized twice a week with a commercial plant nutrient solution containing nitrogen, phosphate, and potassium (20-20-20). Experiments were performed with 5-week-old plants with five or six fully expanded leaves.

Fungal cultures and growth conditions. A tomato isolate of F. oxysporum f. sp. radicis-lycopersici (isolated from naturally infected tomato fruits) was grown on potato dextrose agar (PDA) at $24^{\circ} \mathrm{C}$ and subcultured every week. It was periodically inoculated and reisolated from ripe tomato fruits. The strain of $P$. oligandrum (isolate 1010) used in this study was isolated from pea roots in Denmark. It was grown on PDA or yeast malt agar at $24^{\circ} \mathrm{C}$ in the dark and subcultured every week.

Dual culture tests. Hyphal interactions between $P$. oligandrum and $F$. oxysporum f. sp. radicis-lycopersici were studied according to a previously described procedure (15). Briefly, mycelial plugs ( $5 \mathrm{~mm}$ diameter) collected from actively growing colonies of both fungi were placed $3 \mathrm{~cm}$ apart on the surface of PDA and allowed to grow at $25^{\circ} \mathrm{C}$ under continuous light. The first apparent contact between the antagonist and pathogen occurred by 2 days after inoculation. Mycelial samples from the interaction region were collected at 2, 3, 4, and 5 days after inoculation and processed for electron microscopy.

SEM. Mycelial samples $\left(1 \mathrm{~cm}^{2}\right)$ collected from the interaction region in dual cultures as well as samples from single cultures (control) were vapor-fixed with $2 \%$ (wt/vol) osmium tetroxide in distilled water for $20 \mathrm{~h}$ at room temperature, air-dried, and sputtercoated with gold palladium in a Nanotech sputter coater (Cambridge, England). Samples were kept in a dessicator until examination with a JEOL (Tokyo) JSM-35CF scanning electron microscope operating at $15 \mathrm{kV}$. Micrographs were taken on Polapan (Polaroid Corporation, Cambridge, MA) 400 positive films. Two samples per petri dish per time period were examined.

Root inoculation with $\boldsymbol{P}$. oligandrum. Inoculation of tomato roots with $P$. oligandrum was performed by inoculating the main root with five mycelial plugs (5 $\mathrm{mm}$ diameter). Pythium-inoculated tomato plants were kept in a growth chamber at about $22^{\circ} \mathrm{C}$ with a relative humidity of $75 \%$ for 7 days prior to processing for electron microscopy or challenge with $F$. oxysporum f. sp. radicislycopersici. Samples from Pythium-colonized roots were collected from five plants in three replicate experiments.

Root inoculation with $\boldsymbol{F}$. oxysporum f. sp. radicis-lycopersici. Seven days after inoculation with $P$. oligandrum, tomato plants were inoculated with mycelium from 3-day-old colonies of $F$. oxysporum f. sp. radicis-lycopersici. Fusarium inoculation was performed with a hyphal and spore suspension $\left(10^{8} \mathrm{CFU} / \mathrm{ml}\right)$ prepared by scraping the surface of a petri plate and homogenizing for $5 \mathrm{~s}$ in $15 \mathrm{ml}$ of sterile distilled water in a Waring blender. P. oligandrum-inoculated plants were treated with $0.5 \mathrm{ml}$ of the Fusarium suspension or with $0.5 \mathrm{ml}$ of sterile distilled water, carefully introduced into the soil (as close as possible to the root system) with a sterile syringe. Controls included tomato plants that were not preinoculated with $P$. oligandrum. The pathogen was allowed to 
grow for 8 days in contact with tomato roots before sampling for electron microscopy. Root samples were collected from five plants for each treatment in three replicate experiments.

Tissue processing for transmission electron microscopy (TEM). Mycelial samples $\left(2 \mathrm{~mm}^{3}\right)$ collected from the interaction region of dual fungal cultures and root samples carefully excised at sites of potential pathogen penetration from control and pathogen-inoculated tomato plants were immediately immersed in $3 \%(\mathrm{vol} / \mathrm{vol})$ glutaraldehyde in $0.1 \mathrm{M}$ sodium cacodylate buffer, $\mathrm{pH} 7.2$, for $2 \mathrm{~h}$ at room temperature. They were subsequently postfixed with $1 \%$ (wt/vol) osmium tetroxide in the same buffer for $1 \mathrm{~h}$ at $4^{\circ} \mathrm{C}$ prior to being dehydrated in a graded ethanol series and embedded in Epon 812. Thin sections $(0.7 \mu \mathrm{m})$ cut from the Epon-embedded material with glass knives were mounted on glass slides and stained with $1 \%$ aqueous toluidine blue prior to examination with a Zeiss (Thornwood, NY) axioscope microscope. Ultrathin sections (0.1 $\mu \mathrm{m})$ collected on Formvar-coated nickel grids were either contrasted with uranyl acetate and lead citrate for immediate examination with a JEOL $1200 \mathrm{EX}$ transmission electron microscope operating at $80 \mathrm{kV}$ or processed further for cytochemical labeling. For each treatment, an average of five samples from three different roots were investigated. For each sample, $\sim 15$ ultrathin sections were examined under the electron microscope.

Preparation of gold-complexed probes. Colloidal gold, with particles averaging $12 \mathrm{~nm}$ in diameter, was prepared according to Frens (21), using sodium citrate as a reducing agent. For the localization of cellulosic $\beta$-1,4-glucans, an exoglucanase ( $\beta-1,4-D-$ glucan cellobiohydrolase, EC 3.2.1.21) purified from a cellulase produced by the fungus $T$. harzianum, was complexed to colloidal gold at $\mathrm{pH} 9.0$ and used in a one-step procedure (6). Wheat germ agglutinin (WGA), a lectin with $N$-acetylglucosamine binding specificity, was used for localizing $\mathrm{N}$-acetylglucosamine residues (chitin) according to a previously described procedure (3). Because of its low molecular weight, this lectin could not be directly complexed to colloidal gold. It was used in a two-step procedure, using ovomucoid conjugated to gold at $\mathrm{pH} 5.4$ as a second-step reagent. A $\beta$-1,3-glucanase, purified from tobacco reacting hypersensitively to tobacco mosaic virus, was used for localizing $\beta-1,3-$ glucans according to a recently described method (4). The enzyme was conjugated to colloidal gold at $\mathrm{pH}$ 5.5. Localization of ligninassociated phenolic compounds was performed with a laccase (EC 1.10.3.2) purified from the white rot fungus Rigidoporus lignosus (23). The purified enzyme was complexed to colloidal gold at $\mathrm{pH}$ 4.0, a pH value close to its $\mathrm{pI}$, reported to be 3.83 (8).

Cytochemical labeling. Labeling with the gold-complexed exoglucanase, $\beta$-1,3-glucanase and laccase was performed by incubating the ultrathin sections for 5 to $10 \mathrm{~min}$ on a drop of phosphatebuffered saline-polyethylene glycol (PBS-PEG) at pH 6.0. Sections were transferred to a drop of the enzyme-gold complex for $30 \mathrm{~min}$ at room temperature in a moist chamber. After thorough washing with $\mathrm{PBS}, \mathrm{pH} 7.2$, and rinsing with distilled water, sections were contrasted with uranyl acetate and lead citrate and observed under the transmission electron microscope. For indirect labeling of chitin, sections were first incubated on a drop of PBS, $\mathrm{pH} 7.2$, transferred to a drop of WGA diluted 1:30 in PBS, $\mathrm{pH} 7.2$, and, finally, incubated on a drop of ovomucoid-gold complex (3). Sections were contrasted as described above.

Cytochemical controls. The specificity of the different labelings was assessed by control tests. For direct labelings (i) incubation on gold-complexed enzymes to which were previously added corresponding substrate molecules ( $\beta$-1,4-glucans from barley, laminarin or laminaribiose for $\beta$-1,3-glucanase, and $p$-coumaric acid or ferulic acid for laccase; $1 \mathrm{mg} / \mathrm{ml}$ in PBS, $\mathrm{pH} 7.2$ ); (ii) substitution of the protein-gold complex under study by bovine serum albumin-gold complex to assess the nonspecific adsorption of the enzyme-gold complexes to the tissue sections; and (iii) incubation of the tissue sections with the protein-gold complexes under nonoptimal conditions for biological activity. For indirect labeling of chitin: (i) incubation with WGA to which was previously added $N-N^{\prime}-N^{\prime \prime}$-triacetylchitotriose (1 mg/ml in PBS, $\left.\mathrm{pH} 7.2\right)$; (ii) incubation with uncomplexed ovomucoid followed by incubation with WGA-gold complex; and (iii) incubation with colloidal gold alone.

Reagents. The exoglucanase was provided by C. Breuil, Forintek, Ottawa, Canada, and the aplysia gonaol lectin was obtained from N. Gilboa-Garber, Bar Ilan University, Israël. The laccase was obtained from M. Nicole, ORSTOM, Montpellier, France. Tetrachloroauric acid was purchased from BDH Chemicals, Montreal. All other reagents for electron microscopy were obtained from JBEM Chemical Co., Pointe-Claire, Québec.

\section{RESULTS}

Dual culture tests: SEM and TEM observations. Mycelial samples from single cultures of $P$. oligandrum and $F$. oxysporum $\mathrm{f}$. sp. radicis-lycopersici as well as samples from the interaction region of dual cultures were observed by SEM (Fig. 1). In single cultures, both fungi were composed of dense, branched mycelium (Fig. 1A and B). As early as 2 days after inoculation in dual cultures, close interaction between both fungi was observed, and contact appeared to be established through a thin mucilage readily discernible in some areas (Fig. 1C, arrowhead). Although features of coiling could be observed (Fig. 1C, arrow), the phenomenon was not generalized to all hyphal interactions. At this stage of the colonization process, no external damage was visible on the intertwined hyphae, and usually, it was difficult to clearly distinguish F. oxysporum f. sp. radicis-lycopersici from P. oligandrum. By 3 days after inoculation, macroscopic observations of the plates revealed that $P$. oligandrum developed abundantly and overgrew the F. oxysporum f. sp. radicis-lycopersici colony, easily recognizable by its orange pigmentation.

SEM examination of the interaction region showed that slight wall deformations occurred along the areas of contact between both partners (Fig. 1D). Early signs of hyphal collapse, shown by the wrinkled appearance of the host cell surface, were often observed by 4 days after inoculation (Fig. 1E). Pronounced collapse and loss of turgor of some hyphae were among the most typical features of alteration observed by 5 days after inoculation (Fig. 1F). Although these observations were not sufficient to provide convincing evidence of the antagonistic effect exerted by $P$. oligandrum, they were taken as an indication that close contact between both fungi was a key event, likely preceding damage to $F$. oxysporum f. sp. radicis-lycopersici hyphae. A more precise investigation at the TEM level, thus, was essential to elucidate the nature of this antagonist-pathogen interaction.

Examination of ultrathin sections from mycelial samples collected in the interaction region of 3- to 4-day-old cultures showed that cells of $P$. oligandrum, easily recognized by the strong electron density of their protoplasm, surrounded $F$. oxysporum f. sp. radicis-lycopersici hyphae and frequently penetrated them (Fig. 2A). Hyphal invasion occurred through localized host wall penetration (Fig. 2A, arrow). Pythium ingress in the host cells coincided with extensive cell alterations, such as retraction, aggregation, and, even, dissolution of the cytoplasm, which usually was reduced to a few aggregated remnants (Fig. 2A). At this stage of invasion, host cell wall alterations were not apparent, although some local swelling and shredding could be seen in places. Pythium cells multiplied intensively in the host hyphae. Such massive colonization frequently resulted in strong mechanical pressure against the host hyphal cell walls, ultimately leading to hyphal breakdown and release of actively multiplying Pythium hyphae (Fig. 2D and E). At an advanced stage of the colonization process, hyphae of $F$. oxysporum f. sp. radicis-lycopersici were perforated in many places, and host wall displacement in the direction of Pythium growth was easily discernible (Fig. 2E, arrows).

To confirm the ability of $P$. oligandrum to parasitize $F$. oxysporum f. sp. radicis-lycopersici hyphae, cytochemical tests were 
carried out to study the distribution of cellulose and chitin, known to be the main wall-bound compounds in Pythium and Fusarium, respectively. Incubation of ultrathin sections with gold-complexed exoglucanase for localization of cellulose subunits resulted in regular distribution of gold particles over the cell walls of invading hyphae (Fig. 2B and C). In contrast, labeling was absent over the host cell walls. When WGA/ovomucoid-gold complex for the localization of chitin molecules was applied, a specific deposition of gold particles occurred over the cell walls and septa of altered host hyphae (Fig. 2D). Even at an advanced stage of the interaction, highly disorganized $F$. oxysporum f. sp. radicis-lycopersici cells, often reduced to empty shells, did not show obvious signs of wall degradation, except for some local disruption (Fig. 2E). Labeling was intense and evenly distributed over the preserved wall portions of these damaged hyphae (Fig. 2E). All control tests performed to confirm the specificity of labeling yielded negative results (data not shown).

Light microscope observations of tomato root tissues. Examination of cross-sections of $F$. oxysporum $\mathrm{f}$. sp. radicis-lycopersici-inoculated tomato roots at the light microscope level revealed that the rate and extent of pathogen colonization was markedly reduced in roots previously infected with $P$. oligandrum (Fig. 3).
In control roots grown in the absence of $P$. oligandrum, hyphae of the pathogen proliferated abundantly through much of the epidermis, cortex, endodermis, and paratracheal parenchyma cells and rapidly reached the vascular stele, in which they massively colonized the xylem vessels (Fig. 3A). Fungal growth occurred intraand intercellularly, and direct host wall penetration by means of constricted hyphae was observed frequently (Fig. 3A, arrowheads). Pathogen ingress toward the vascular stele coincided with extensive cell alterations, such as aggregation of the cytoplasm, organelle disintegration, and host cell wall dissolution or breakdown (Fig. 3). In massively invaded root tissues, such as the endodermis, host cell walls were altered markedly, shown by their decrease in electron density and loss of structural integrity (Fig. 3A, arrows). Cell breakdown due to host cell wall disruption frequently resulted in tissue maceration. In these control roots, pathogen penetration failed to stimulate plant cell wall responses, shown by the absence of typical host reactions such as formation of wall appositions or intercellular space occlusions.

Observations of tomato root samples inoculated with $P$. oligandrum but not challenged with $F$. oxysporum f. sp. radicis-lycopersici showed a large number of fungal hyphae that had grown on the root surface and established intimate contact with the host
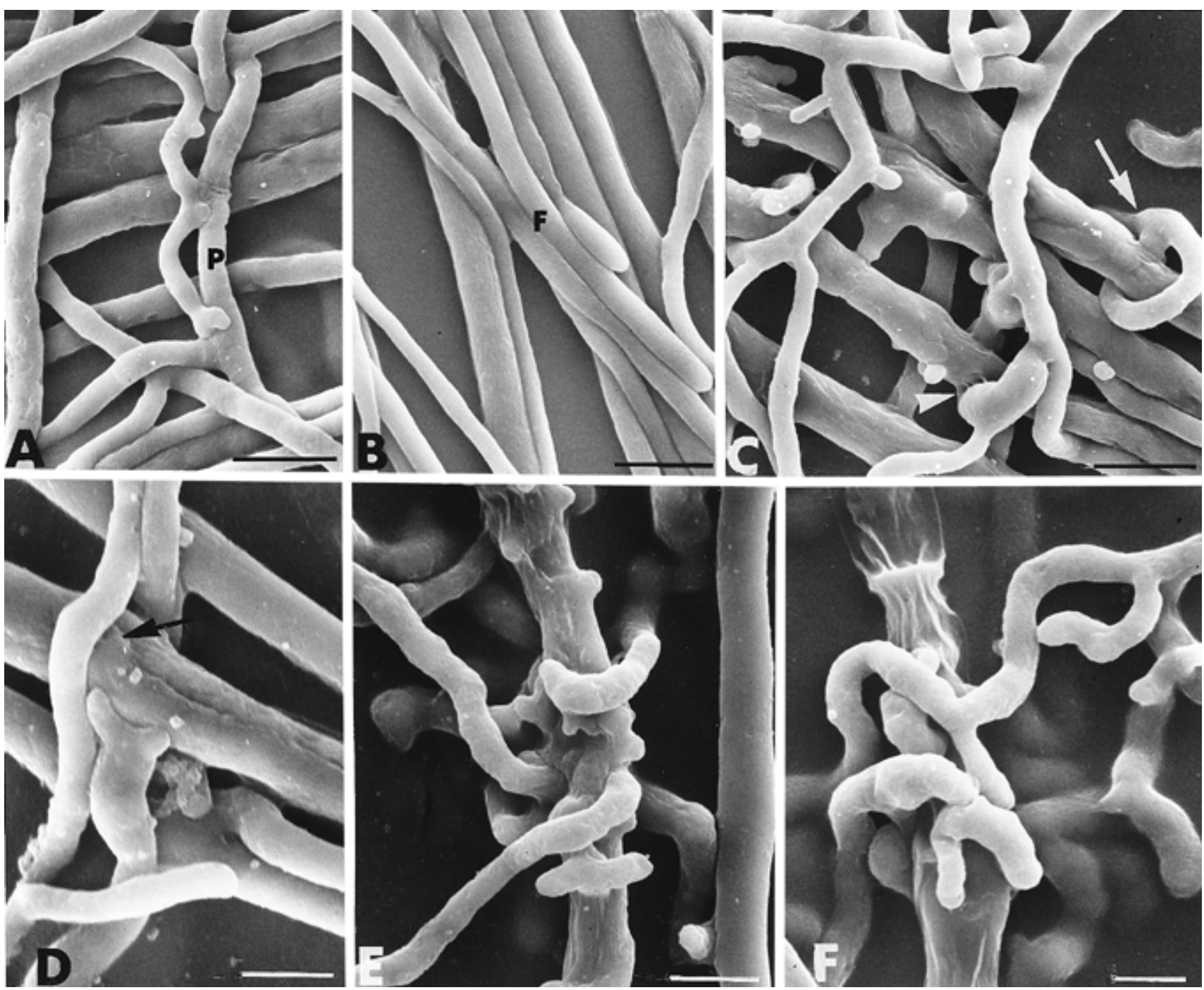

Fig. 1. Scanning electron micrographs of Pythium oligandrum hyphae interacting with cells of Fusarium oxysporum $\mathrm{f}$. sp. radicis-lycopersici in dual cultures. A and B, Controls grown in pure culture. A, P. oligandrum $(\mathrm{P})$ and $\mathbf{B}, F$. oxysporum f. sp. radicis-lycopersici (F). Both fungi form a dense, branched mycelium. $\times 1,500$; bar $=10 \mu \mathrm{m}$. C through F, Hyphal interactions in dual cultures 2, 3, 4, or 5 days after inoculation, respectively. $\mathbf{C}$, Hyphae of both fungi appear closely intertwined with hyphae of $F$. oxysporum f. sp. radicis-lycopersici. Contact between the fungi is apparently established through a thin mucilage (arrowhead). Features of coiling are observed (arrow). $\times 1,500 ;$ bar $=10 \mu \mathrm{m}$. D, Slight wall deformations are seen along the areas of contact (arrow). $\times 2,400 ;$ bar $=5 \mu \mathrm{m} . \mathbf{E}$, Early signs of collapse, shown by the wrinkled appearance of the cell surface of some hyphae, are observed. $\times 2,400$; bar $=5 \mu \mathrm{m}$. F, Marked collapse and loss of turgor of some cells is observed. $\times 2,000$; bar $=5 \mu \mathrm{m}$. 

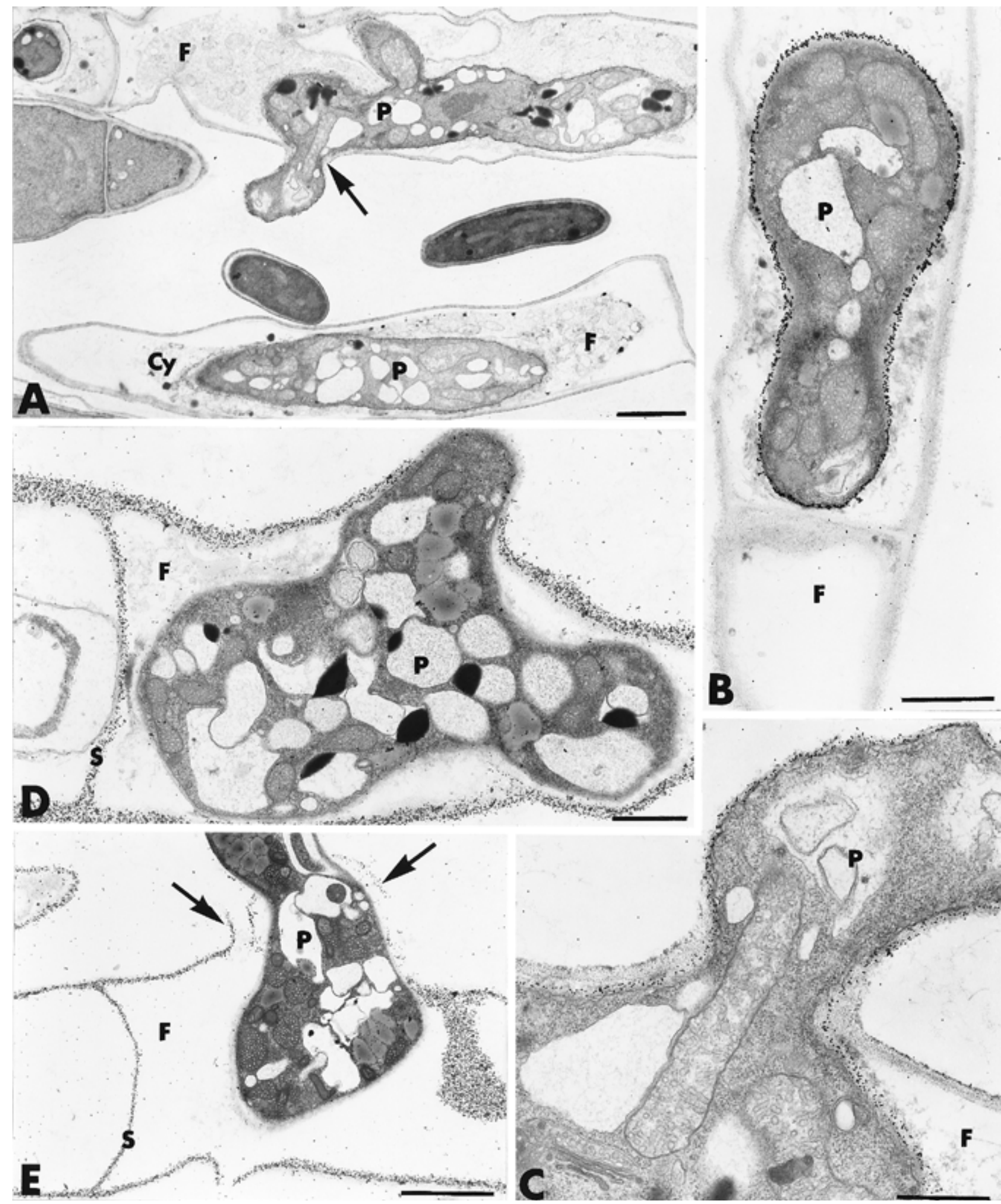

Fig. 2. Transmission electron micrographs of Pythium oligandrum hyphae interacting with cells of Fusarium oxysporum f. sp. radicis-lycopersici in dual cultures. A, Cells of P. oligandrum $(\mathrm{P})$, characterized by the strong electron density of their protoplasm, surround $F$. oxysporum f. sp. radicis-lycopersici $(\mathrm{F})$ hyphae and frequently penetrate them. Hyphal invasion occurs through localized host wall penetration (arrow). The cytoplasm (Cy) of penetrated host cells is reduced to a few aggregated remnants. $\times 6,000 ;$ bar $=2 \mu \mathrm{m}$. B and C, Labeling with gold-complexed exoglucanase. Regular distribution of gold particles is seen over the cell walls of invading Pythium hypha, whereas labeling is absent over the Fusarium cell walls. The massive colonization of Fusarium hyphae results in the release of actively multiplying Pythium hyphae. $\times 16,000$; bar $=1 \mu \mathrm{m}$. D and E, Labeling with wheat germ agglutinin/ovomucoid-gold complex. The cell walls and septa (S) of highly disorganized $F$. oxysporum f. sp. radicis-lycopersici cells, often reduced to empty shells, are intensely and regularly labeled. Fungal wall breakdown is observed (arrows). D, $\times 13,000 ;$ bar $=1 \mu \mathrm{m}$. E, $\times 8,000$; bar $=2 \mu \mathrm{m}$. 


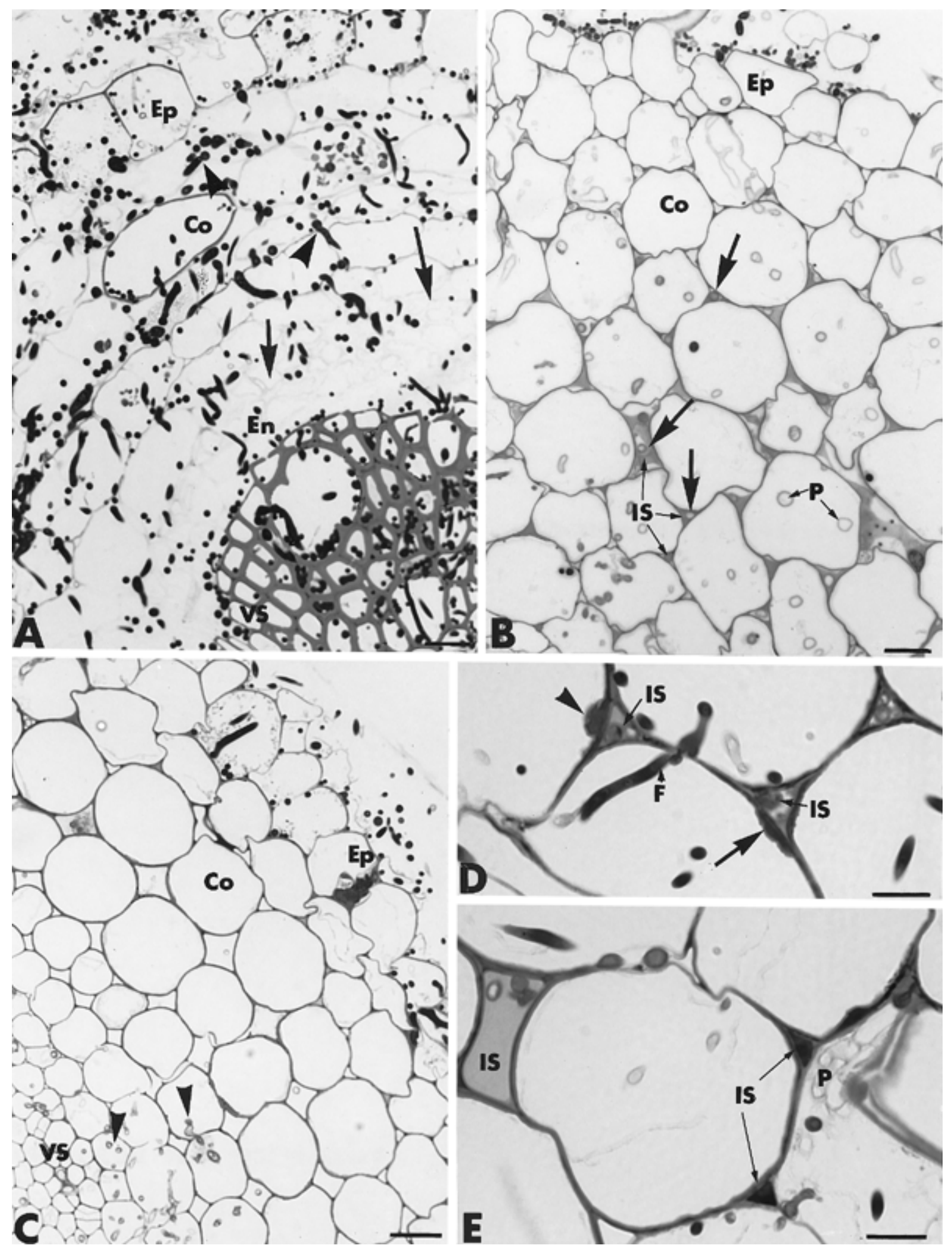

Fig. 3. Light micrographs of samples from tomato roots. A, Sample from control tomato root collected 2 days after inoculation with Fusarium oxysporum f. sp. radicis-lycopersici. Hyphae of the pathogen multiply abundantly in the epidermis (Ep), cortex (Co), and endodermis (En) and reach the vascular stele by centripetal growth. Fungal growth occurs intra- and intercellularly. Pathogen ingress toward the vascular stele coincides with pronounced cell wall alterations (arrows). Arrowheads indicate direct host wall penetration by constricted hyphae. $\times 400 ;$ bar $=20 \mu \mathrm{m}$. B, Sample from control Pythium oligandrum-inoculated tomato root collected 2 days after inoculation. The fungus (P) disseminates through much of the tissues by inter- and intracellular modes of growth. Hyphae growing within the root tissues appear swollen in addition to being less intensely stained with toluidine blue than those colonizing the root surface. Most intercellular spaces (IS) are occluded by a densely stained material in which Pythium hyphae are trapped (arrows). $\times 400 ;$ bar $=20 \mu \mathrm{m}$. C through E, Sample from $P$. oligandrum-inoculated tomato root collected 2 days after challenge with $F$. oxysporum f. sp. radicis-lycopersici (F). Fungal growth is mainly restricted to the outermost root tissues including the epidermis and first outer cortical layers. Pathogen penetration in the epidermis coincides with the formation of wall thickenings that are densely stained with toluidine blue. Pythium cells are seen in the vascular stele (VS; arrowheads). Wall appositions formed in the invaded areas vary in shape from elongated deposits along a large portion of the cell wall (D, arrow) to hemispherical protuberances (D, arrowhead). Intercellular spaces are occluded by a material densely stained with toluidine blue. C, $\times 400$; bar $=20 \mu \mathrm{m}$. D and $\mathbf{E}, \times 1,000$; bar $=10 \mu \mathrm{m}$. 
epidermis (Fig. 3B). Observation of about 50 sections from 10 different roots provided evidence that the fungus was able to penetrate the root epidermis without extensive host wall degradation and, subsequently, disseminate through much of the tissues by interand intracellular modes of growth (Fig. 3B). The invading hyphae appeared swollen and were less intensely stained with toluidine blue than those colonizing the root surface (Fig. 3B). Interestingly, a typical feature of this interaction was the occlusion of most intercellular spaces with a densely stained material. Pythium cells frequently were trapped in this material (Fig. 3B, arrows).

In $P$. oligandrum-inoculated tomato roots challenged with $F$. oxysporum f. sp. radicis-lycopersici, the pattern of colonization by the pathogen differed markedly from that observed in control roots grown in the absence of Pythium (Fig. 3C). Fusarium growth in planta was apparently restricted to the outermost root tissues, including the epidermis and, occasionally, the outermost cortical cells (Fig. 3C). Hyphae of the pathogen were never detected in inner root tissues. In contrast, Pythium cells, easily recognizable by their empty shell appearance, could be seen in all tissues, including the vascular stele (Fig. 3C, arrowheads). Pathogen penetration in the root epidermis was associated with cytological changes, mainly characterized by the elaboration of structural barriers in the regions proximal to potential fungal penetration (Fig. 3D and E). Wall thickenings frequently were observed in the reacting epidermal and outer cortical host cells. They appeared intensely stained and heterogeneous in shape, ranging from elongated deposits (Fig. $3 \mathrm{D}$, arrows) to hemispherical protuberances resembling papillae (Fig. 3D, arrowhead). In addition to the formation of wall appositions, another typical host reaction in the colonized area was the plugging of most intercellular spaces with a material that stained densely with toluidine blue (Fig. 3D and E). Such host reactions were confined to the area of potential fungal spread and were never seen in $F$. oxysporum f. sp. radicis-lycopersici-inoculated control root samples. These observations suggested that prior inoculation of tomato roots with $P$. oligandrum induced a number of host reactions that culminated in the formation of structural barriers that likely protected the inner root tissues from pathogen invasion. A more precise investigation at the TEM level was essential to precisely evaluate the pattern of colonization by both fungi and to gain further insight into the functional significance of the host reactions in restricting pathogen growth and development.

Cytology of infection of tomato root tissues by $\boldsymbol{F}$. oxysporum f. sp. radicis-lycopersici. Examination of $\sim 15 F$. oxysporum f. sp. radicis-lycopersici-infected root samples collected 3 days after inoculation from tomato seedlings grown in the absence of $P$. oligandrum showed that the pathogen had ramified abundantly through much of the root tissues, causing extensive host cell damage (Fig. 4A and B). At this stage of infection, mycelial growth occurred inter- and intracellularly (Fig. 4A). Colonization of the vascular stele proceeded via the infection of the endodermis and the paratracheal parenchyma cells and progressed through direct penetration of the pit membranes (Fig. 4C, arrow). Fungal ingress toward the vascular stele coincided with marked cell wall damage, involving loosening of the fibrillar layers (Fig. 4B) accompanied by disruption of the primary walls and middle lamella matrices and, in some cases, complete wall breakdown leading to tissue maceration. Incubation with gold-complexed $\beta$-1,4-exoglucanase revealed that cellulose subunits were distributed randomly over the strands of disorganized wall fibrils (Fig. 4B). Typical features of host reactions, such as formation of wall appositions, intercellular space plugging, and vascular occlusion (i.e., gelation, tyloses, and phenolic deposition), could not be detected. This massive fungal colonization, associated with drastic alteration of the root tissues, coincided with the presence of numerous dark brown lesions on the root system and expression of symptoms, including leaf chlorosis and wilting.

Cytology of infection of tomato root tissues by $P$. oligandrum. Examination of transverse sections of root samples taken from tomato plants inoculated with $P$. oligandrum revealed that a large number of fungal hyphae had grown on the root surface and established intimate contact with the host exodermis (data not shown). Once in the epidermis, the fungus progressed rapidly (within $48 \mathrm{~h}$ ) toward internal tissues through inter- and intracellular modes of growth (Fig. 4D and E). Although a few fungal cells exhibited a normal appearance, characterized by a dense cytoplasm surrounded by a thin cell wall (Fig. 4D), most invading hyphae $(90 \%)$ were reduced to empty shells, in which the only recognizable structure was the cell wall specifically labeled by exoglucanase-gold complex (Fig. 4E). Surprisingly, attempted host wall penetration by such altered fungal cells frequently was observed. Fungal colonization of the root tissues was not associated with host cell alterations similar to those recorded in the tomato- $F$. oxysporum f. sp. radicis-lycopersici interaction. In contrast, a close examination of the invaded areas revealed the occurrence of some host reactions at sites of potential penetration. Such reactions included the occlusion of several intercellular spaces by a fibrillogranular material (Fig. 4D) and the formation of heterogeneous wall appositions, resembling papillae, in noninfected host cells adjacent to invaded ones (Fig. 4E). Wall appositions that formed in the reacting host cells varied in size, shape, and structure. They usually appeared to be made up of an amorphous matrix in which polymorphic, electron-dense structures were embedded (Fig. 4E). Accumulation of an electron-opaque material lining the primary walls in some intercellular spaces and extending toward the inside to form polymorphic aggregates that apparently interacted with the wall of the fungus also was observed often (data not shown).

Cytology of infection of $P$. oligandrum-inoculated tomato root tissues by $\boldsymbol{F}$. oxysporum f. sp. radicis-lycopersici. TEM examination of $F$. oxysporum $\mathrm{f}$. sp. radicis-lycopersici-infected root samples collected 8 days after inoculation from tomato plants grown in the presence of $P$. oligandrum revealed marked changes in the rate and extent of root colonization by the pathogen. Indeed the intensity of colonization was drastically reduced compared to that observed in control, inoculated plants, and pathogen growth was limited strictly to the epidermis and first outer cortical cell layers (Fig. 5). Intimate interactions between $F$. oxysporum f. sp. radicislycopersici and P. oligandrum, often associated with marked damage of pathogen cells, were detected in colonized root tissues (Fig. 5A). Such changes were observed in all root samples examined.

To confirm that the antagonistic potential expressed by $P$. oligandrum in dual culture tests also occurred in planta, we became interested in finding out whether this mycoparasite also could have a deleterious effect on the Fusarium hyphae that escaped the first defense line in the rhizosphere. Observation of numerous sections from at least five different roots suggested that $P$. oligandrum could interact physically with the pathogen, causing cytological damages similar to those seen in dual culture tests (Fig. 5A and B). Based on our ultrastructural observations, we suspect that Pythium cells are able to penetrate and grow within hyphae of the pathogen. Because both fungi could be distinguished easily by means of differential cell wall labeling, both the exoglucanase and WGA/ovomucoid-gold complexes were applied to tissue sections. When incubated with the WGA/ovomucoid-gold complex, a regular deposition of gold particles occurred over the walls of penetrated fungal cells, which usually were reduced to empty, pleomorphic shells (Fig. 5D). In contrast, no labeling was detected over the walls of invading hyphae parasitizing altered fungal cells. When tissue sections were treated with gold-complexed exoglucanase, an inverse labeling pattern was obtained. Penetrated fungal cells were unlabeled, whereas gold particles were specifically associated with the walls of most internal fungal cells (Fig. 5E). The specificity of this labeling was assessed by the regular distribution of gold particles over the plant cell wall. All control tests, including previous adsorption of the probes with target substrate molecules, resulted in a near absence of labeling over plant and fungal cell walls (data not shown). 


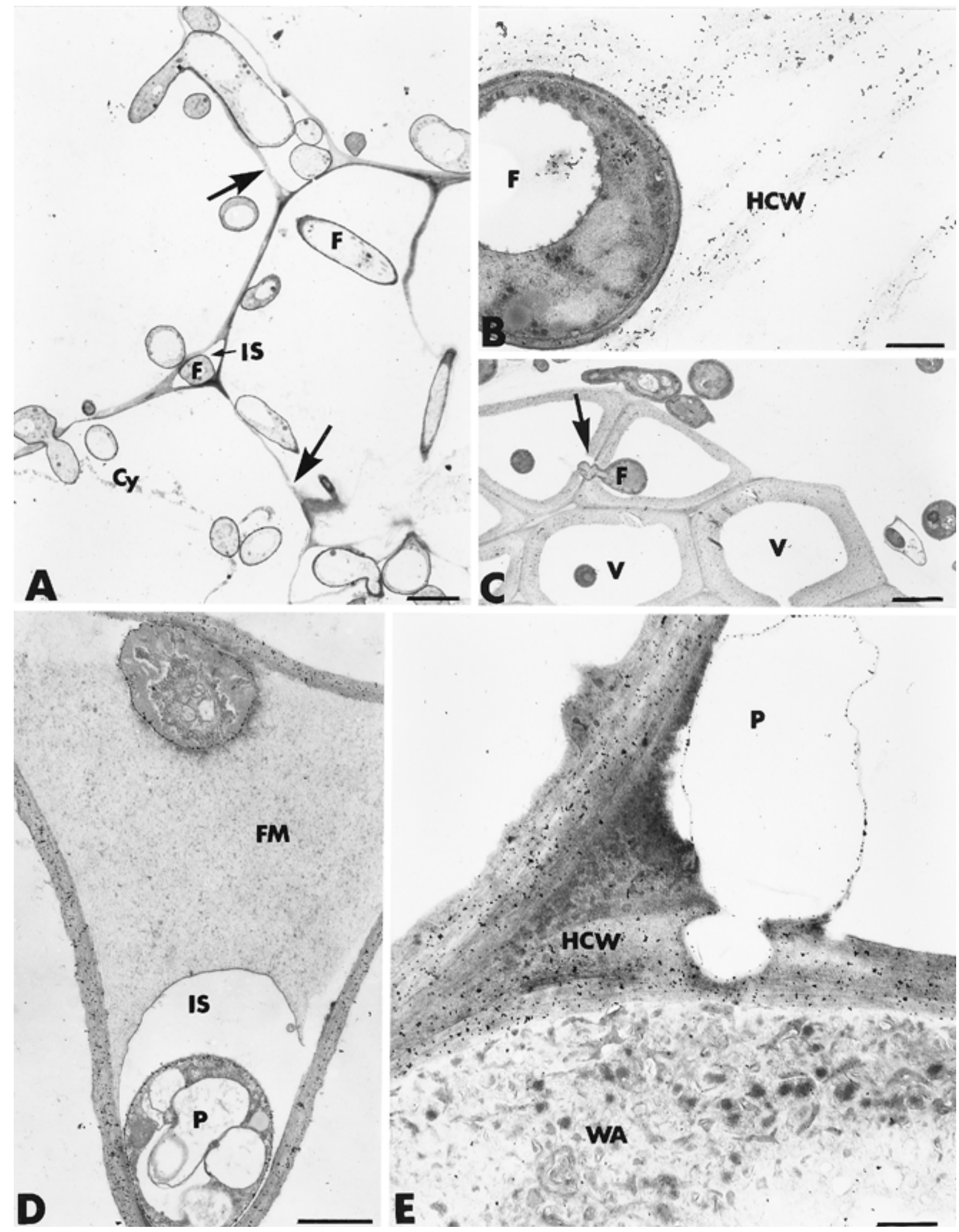

Fig. 4. Transmission electron micrographs of control tomato root tissues collected 5 days after inoculation with either A through C, Fusarium oxysporum f. sp. radicis-lycopersici or $\mathbf{D}$ and $\mathbf{E}$, Pythium oligandrum. A through $\mathbf{C}, F$. oxysporum $\mathrm{f}$. sp. radicis-lycopersici-inoculated tomato roots. The fungus (F) multiplies abundantly in the cortical area, causing pronounced cell disorganization and host cell wall alteration (A, arrows). The host cytoplasm (Cy) is reduced to a fine strand of aggregated material. When cellulose is labeled with $\beta$-1,4-exoglucanase-gold complex, gold particles are randomly distributed over the loosened host cell wall (HCW) (B) and are associated with isolated wall fibrils. Fusarium hyphae are seen in the xylem vessels (V). Colonization of the vascular stele proceeds through direct penetration of the pit membranes $(\mathbf{C}$, arrow). A and $\mathbf{C}, \times 3,000$; bar $=3 \mu \mathrm{m}$. B, $\times 20,000$; bar $=0.5 \mu \mathrm{m}$. IS $=$ intercellular space. D and E, $P$. oligandrum-inoculated tomato root tissues. Although a few Pythium (P) cells exhibit a normal appearance (D), other invading hyphae are reduced to empty shells in which the only recognizable structure is the cell wall, specifically labeled by exoglucanase-gold complex (E). Attempted host wall penetration by such altered fungal cells is observed. Invaded intercellular spaces are occluded by a fibrillo-granular material (FM). The formation of a heterogeneous wall apposition (WA) is seen in a noninfected host cell adjacent to an invaded one. $\mathbf{D}, \times 13,000$; bar $=1 \mu \mathrm{m}$. $\mathbf{E}, \times 20,000$; bar $=0.5 \mu \mathrm{m}$. 


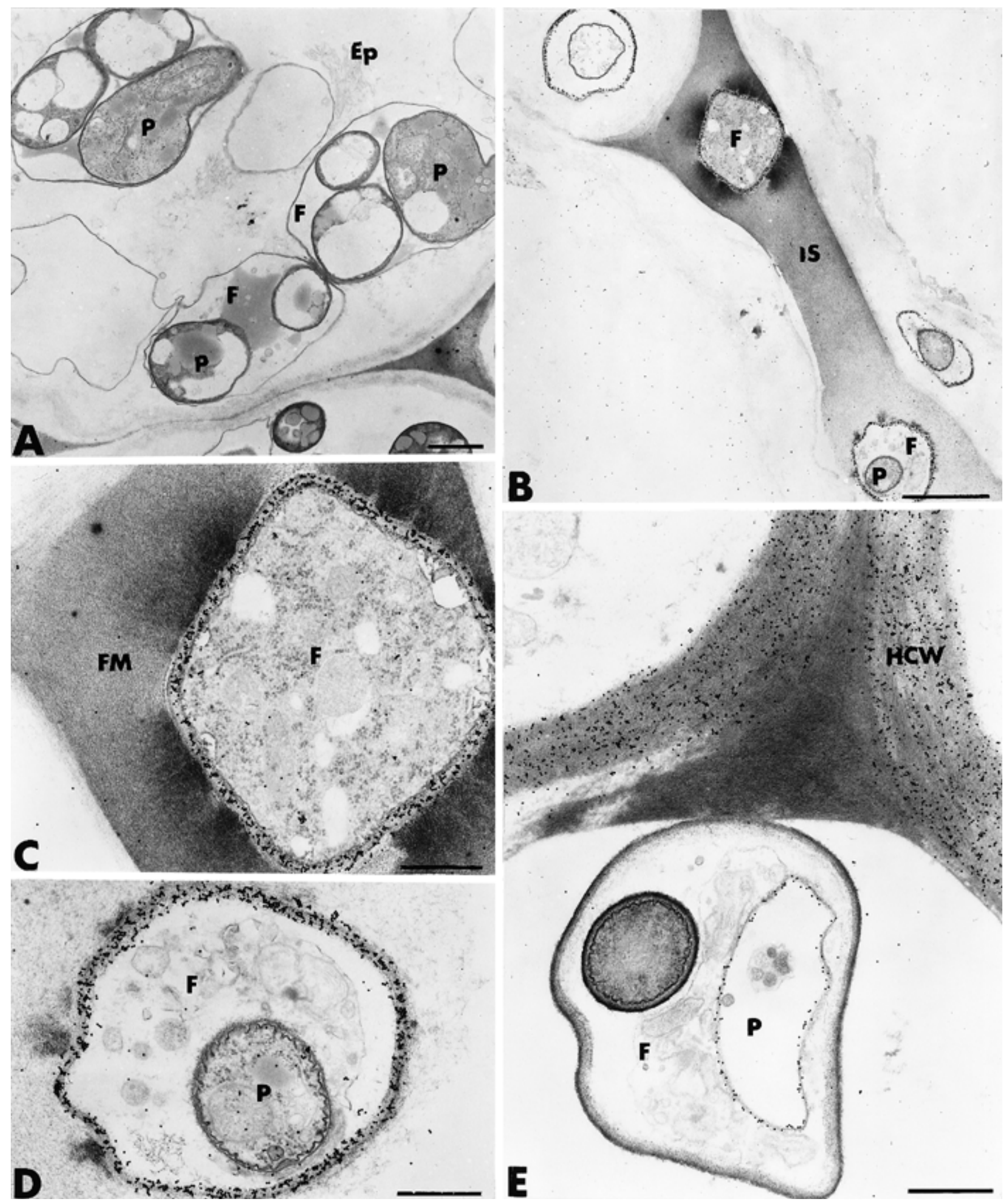

Fig. 5. Transmission electron micrographs of Pythium oligandrum-inoculated tomato root tissues collected 5 days after challenge with Fusarium oxysporum $\mathrm{f}$. sp. radicis-lycopersici. A, Intimate interactions between $F$. oxysporum f. sp. radicis-lycopersici $(\mathrm{F})$ and P. oligandrum $(\mathrm{P})$, often associated with marked damage to pathogen cells, are detected in the colonized root epidermis (Ep). $\times 10,000$; bar $=1 \mu \mathrm{m}$. B through $\mathbf{D}$, Labeling with wheat germ agglutinin/ovomucoid-gold complex. Regular deposition of gold particles occurred over the walls of penetrated fungal cells, which are often reduced to empty, pleomorphic shells (D). In contrast, no labeling is detected over the walls of Pythium hyphae parasitizing the altered fungal cells. Fungal cells are trapped in the fibrillar material (FM) formed in intercellular spaces (IS). B, $\times 8,000 ;$ bar $=2 \mu \mathrm{m}$. C and D, $\times 30,000 ;$ bar $=0.5 \mu \mathrm{m}$. E, Labeling with gold-complexed exoglucanase. Regular distribution of gold particles is seen over the cell walls of a Pythium hypha colonizing a Fusarium cell that is unlabeled. The host cell wall (HCW) is intensely labeled. $\times 30,000 ;$ bar $=0.5 \mu \mathrm{m}$. 
Pathogen cell alteration did not occur only on contact with $P$. oligandrum. Indeed, marked changes in both the morphology and ultrastructure of $F$. oxysporum f. sp. radicis-lycopersici hyphae frequently were observed at a distance from $P$. oligandrum (Fig. $5 \mathrm{~B}$ and $\mathrm{C})$. Such changes usually coincided with the formation of an unusual fibrillar network in most intercellular spaces (Fig. 5B). Fungal cells trapped in this material appeared disorganized (Fig. 5C) and, in some cases, were totally depleted of protoplasm. Incubation of ultrathin sections with WGA/ovomucoid-gold complex resulted in regular deposition of gold particles over the walls of these fungal cells (Fig. 5C).

Pathogen ingress toward the cortical area was associated with several attempts to penetrate the host cell wall. However, most of these attempts failed, mainly because $F$. oxysporum f. sp. radicislycopersici hyphae were halted in the course of their development by the formation of structural barriers (Fig. 6). The wall appositions formed in the reacting host cells were highly heterogeneous in size, shape, and texture (Fig. 6A and B). Although they could be either stratified, granular and of very high electron density, or amorphous, they all appeared to be made of an underlying matrix on which encrusting substances subsequently were deposited (Fig. $6)$. Frequently, the wall appositions were delimited by a band of electron-opaque material (Fig. 6A and E). The host cell wall itself displayed a higher electron density than normal, indicating the probable infiltration of structural molecules (Fig. 6A and C). Attempts to progress from one cell to another through penetration of the wall appositions usually aborted, illustrated by the presence of altered penetration pegs within the deposited material (Fig. 6B). Such host reactions occurred always in the first tissue layers underlying the invaded epidermis and were not seen in the inner tissues.

To further define the chemical nature of the wall appositions formed in the root tissues of $P$. oligandrum-inoculated tomato plants when challenged with $F$. oxysporum $\mathrm{f}$. sp. radicis-lycopersici, cytochemical tests were carried out. Application of $\beta$-1,4-exoglucanasegold complex to ultrathin sections resulted in heavy deposition of gold particles over the host cell walls (Fig. 6A). Labeling also occurred over the wall appositions, but it was irregularly distributed, shown by the predominant association of gold particles with the electron-opaque layer bordering the central core of the apposition (Fig. 6A). When sections were incubated with tobacco $\beta-1,3$-glucanase, a considerable number of gold particles was detected over all wall appositions, regardless of their size, shape, texture, and architecture (Fig. 6C through E). In contrast, the fibrillar material accumulating in some intercellular spaces was free of labeling (Fig. 6C and D). Similarly, the band of electron-opaque material bordering the appositions appeared nearly unlabeled (Fig. 6E). Control tests, including incubation of enzyme-gold complex with laminarin prior to section labeling, yielded negative results (data not shown).

Incubation of sections with gold-complexed laccase resulted in intense deposition of gold particles over both the host cell walls and wall appositions (Fig. 7A and B). In the appositions, labeling was scattered and apparently less intense than that obtained when incubated with $\beta$-1,3-glucanase (Fig. 7A). The intensity of labeling over the host cell walls varied from a few scattered gold particles in some areas (Fig. 7A) to numerous particles in other areas (Fig. 7B). Labeling was distributed more regularly over the heterogeneous material accumulating in the intercellular spaces (Fig. 7C). Electron-dense deposits formed in the lumen of reacting host cells also were specifically labeled (Fig. 7D, arrows). Incubation of enzyme-gold complex with either ferulic or $p$-coumaric acid prior to section treatment abolished the labeling over the cell walls and wall appositions (data not shown).

\section{DISCUSSION}

Because of the initial description of $P$. oligandrum as a secondary invader of necrotized roots (18), an increasing number of re- ports have identified this fungus as one of the most widely distributed Pythium spp. in a number of cultivated soils $(36,39,44)$. However, in spite of renewed interest in exploiting $P$. oligandrum as an alternative for controlling root diseases, examples of practical use are few, even though encouraging results have been reported with the use of $P$. oligandrum-coated seeds for controlling damping-off caused by $P$. ultimum in cress and sugar beet (37). Previous studies have relied primarily on investigating microbial interactions in the rhizosphere and have nearly ignored the host plant, although there are good reasons to believe that the association between $P$. oligandrum and root tissues may affect, to some extent, plant physiology, possibly leading to activation of defense genes when challenged by a pathogen.

Based on the current results, it is clear that tomato plants grown in the presence of $P$. oligandrum afford increased resistance against F. oxysporum f. sp. radicis-lycopersici attack. Although the exact mechanisms by which this antagonist operates to limit pathogen invasion are not fully elucidated, our cytological results demonstrate that the beneficial effect of $P$. oligandrum in repressing $F$. oxysporum f. sp. radicis-lycopersici growth and development relies on strong antagonistic activity associated with induction of structural and biochemical barriers in host tissues. The current results confirm earlier microscopic observations on the potential of $P$. oligandrum to establish close contact with root cells and provide new insights into the mechanisms by which increased protection against pathogen attack is conferred.

SEM investigations of the interaction region between both fungi demonstrated that damage to $F$. oxysporum $\mathrm{f}$. sp. radicis-lycopersici hyphae began to appear soon after close contact was established with $P$. oligandrum. This observation provides evidence supporting the assumption that the outcome of the interaction is likely determined by initial contact events that trigger firm binding of the antagonist to the host, leading ultimately to pathogen death. The rapid collapse and loss of turgor of $F$. oxysporum f. sp. radicis-lycopersici hyphae suggests that the antagonist produced antifungal substances. Ultrastructural observations of sections from the interaction regions in dual culture tests confirmed that intimate contact between hyphae of $P$. oligandrum and cells of the pathogen resulted in a series of disturbances, including generalized disorganization of the host cytoplasm, retraction of the plasmalemma, and, finally, complete loss of the protoplasm. These results are in line with previous observations that described the deleterious effect of $P$. oligandrum on both the morphology and ultrastructure of various fungal pathogens $(32,34)$.

In all examined samples, hyphal penetration of the antagonist into cells of the pathogen was seldom associated with marked host cell wall alterations. This was corroborated by the pattern of labeling obtained with WGA/ovomucoid-gold complex, which showed that, except in the area of hyphal penetration, the chitin component of the host cell walls was structurally preserved at a time when the host cytoplasm had undergone complete disorganization. These observations indicated that production of cell wall-degrading enzymes by $P$. oligandrum probably was not an early event involved in the antagonistic process as previously suggested by Elad et al. (19) in the case of $P$. nunn. The observed $F$. oxysporum f. sp. radicis-lycopersici cell reactions after invasion by $P$. oligandrum recall alterations detected in fungal cells treated with some fungicides or exposed to antibiotics (27). A similar scheme of reactions was recently described by Bélanger et al. (2) who reported that the antagonistic properties of a Québec isolate of $T$. harzianum, strain MAUL-57, against Botrytis cinerea were associated primarily with antibiosis, whereas production of hydrolytic enzymes appeared to be a secondary event probably associated with final pathogen disintegration.

Although it is clear that enzymes produced by $P$. oligandrum play a major role in breaching host cell walls at sites of attempted host penetration, it seems likely that further enzymatic production contributes more to the saprophytic phase of the antagonist, when 


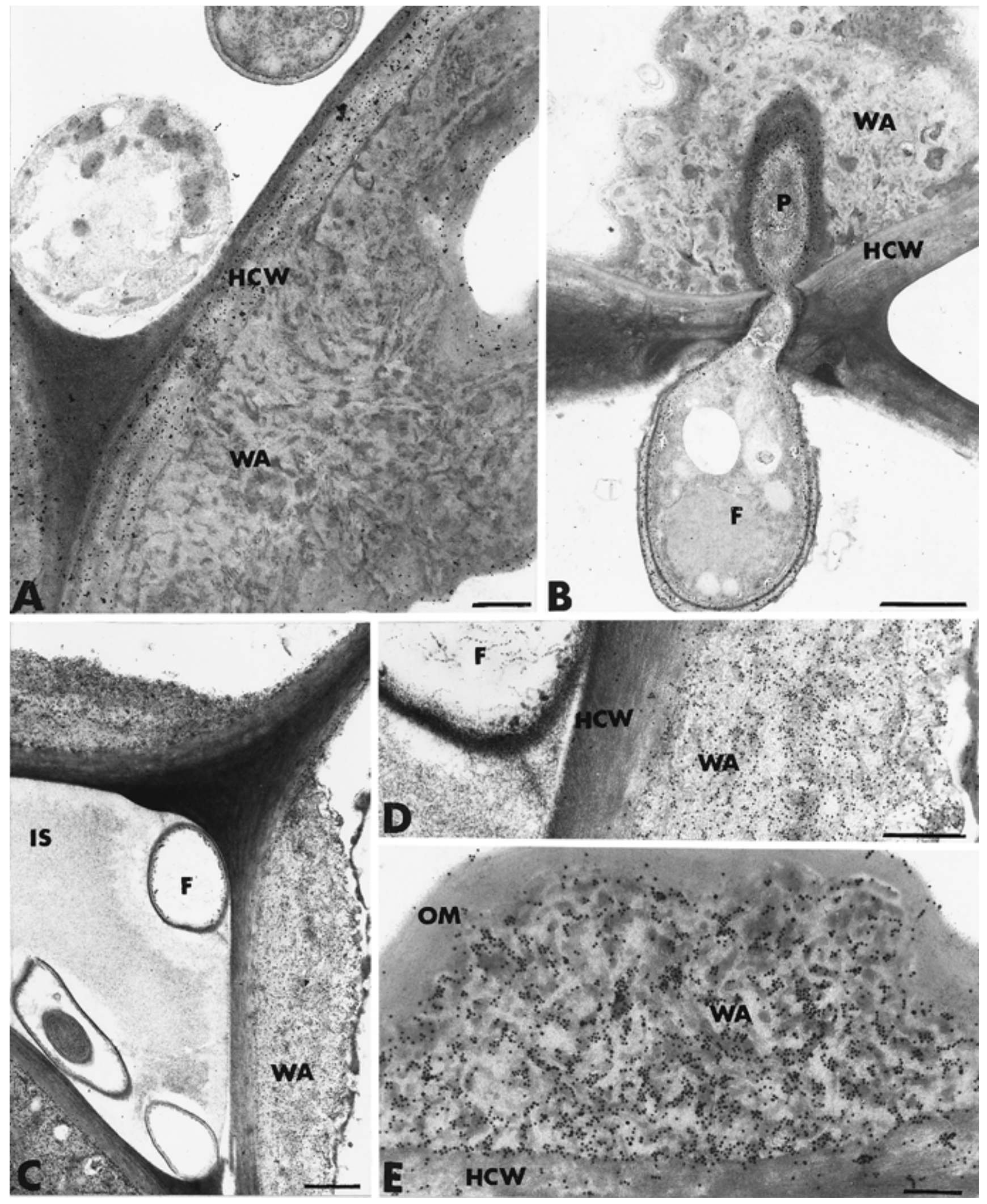

Fig. 6. Transmission electron micrographs of Pythium oligandrum-inoculated tomato root tissues collected 5 days after challenge with Fusarium oxysporum $\mathrm{f}$. sp. radicis-lycopersici. A, Labeling with gold-complexed exoglucanase. The host cell wall (HCW) is heavily labeled, whereas gold particles are specifically associated with the electron-opaque layer bordering the central core of the wall apposition (WA). $\times 20,000$; bar $=0.5 \mu \mathrm{m}$. B, Labeling with wheat germ agglutinin/ovomucoid-gold complex. Regular deposition of gold particles occurs over the walls of a Fusarium (F) cell. An unsuccessful attempt to penetrate a wall apposition is visible and illustrated by the presence of an altered penetration peg $(\mathrm{P})$ within the deposited material. $\times 16,000 ;$ bar $=1 \mu \mathrm{m}$. $\mathbf{C}$ through $\mathbf{E}$, Labeling with gold-complexed $\beta$-1,3-glucanase. The wall appositions are intensely labeled, whereas the opaque surrounding material (OM) is nearly free of labeling. Some gold particles occur over the host cell wall. $\mathbf{C}, \times 10,000$; bar $=1 \mu \mathrm{m}$. IS = intercellular space. $\mathbf{D}, \times 30,000$; bar $=0.5 \mu \mathrm{m}$. E, $\times 40,000$; bar $=0.25 \mu \mathrm{m}$. 
the cell content is utilized as a food source, providing the energy required to multiply abundantly. Interestingly, the same antagonistic process was observed in planta. The specific labeling patterns obtained with the exoglucanase-gold and WGA-ovomucoid-gold complexes confirmed that $P$. oligandrum successfully penetrated invading cells of the pathogen without causing substantial cell wall alterations, shown by the intense labeling of chitin.

In agreement with earlier reports (36), our cytological observations confirmed that $P$. oligandrum displayed the ability to colonize root tissues without inducing extensive cell damage, which

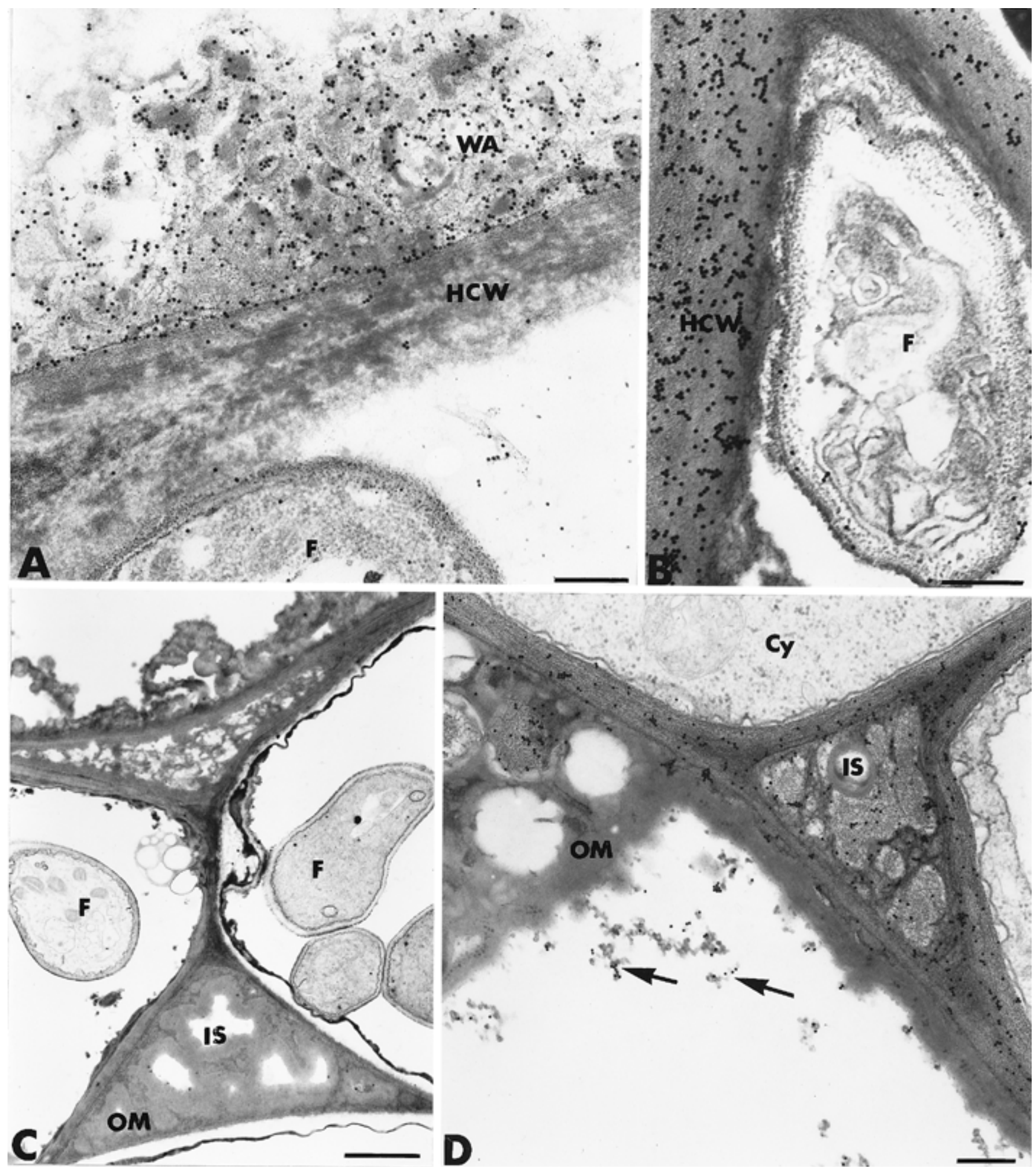

Fig. 7. Transmission electron micrographs of Pythium oligandrum-inoculated tomato root tissues collected 5 days after challenge with Fusarium oxysporum f. sp. radicis-lycopersici. A and B, Labeling with gold-complexed laccase. Intense deposition of gold particles is seen over a wall apposition (WA). The intensity of labeling over the host cell walls $(\mathrm{HCW})$ varies from a few scattered gold particles in some areas $(\mathbf{A})$ to numerous particles in other areas $(\mathbf{B})$. $\mathrm{F}=$ Fusarium. $\mathbf{A}, \times 50,000$; bar $=0.25 \mu \mathrm{m}$. B, $\times 70,000 ;$ bar $=0.20 \mu \mathrm{m}$. C, Intercellular spaces (IS) are occluded by an osmiophilic material $(\mathrm{OM}) . \times 13,000 ;$ bar $=1 \mu \mathrm{m}$. D, Labeling with gold-complexed laccase. Although no labeling is detected over the electron-opaque aggregates (OM) lining the host cell wall, probably because of the high compactness of this material, gold particles are specifically associated with the fine electron-opaque flecks likely released from the aggregated material (arrows). Labeling occurs also in the occluded intercellular spaces. No labeling is seen in the host cytoplasm $(\mathrm{Cy}) . \times 40,000 ; \mathrm{bar}=0.25 \mu \mathrm{m}$. 
occurs in several host-Pythium interactions $(16,38)$. However, a novel finding concerned the structural alteration of the invading hyphae, evidenced by the frequent occurrence of empty fungal shells in the root tissues. Whether such alterations are attributable to the creation of a fungitoxic environment associated with the synthesis and accumulation of antimicrobial compounds by the reacting host cells or simply relate to a specific behavior of the fungus in planta remains to be fully elucidated. Whatever the process involved in this fungal cell degradation, it is clear that $P$. oligandrum ramifies in all root tissues.

This obviously implies that at least small amounts of cell wall hydrolytic enzymes, such as pectinases and cellulases, are produced to locally weaken or loosen the host cell walls, facilitating spread into root tissues. Indeed, the regular pattern of cellulose distribution in the internal root tissues was taken as an indication that cell wall-degrading enzymes were very slightly produced inside the plant. This situation contrasts with that reported in several plant-Pythium interactions, in which drastic host wall degradation leading to tissue maceration is commonly observed (16).

Considering the specific relationship established between $P$. oligandrum and plant cells, one may be tempted to establish a parallel with endomycorrhizal infections as suggested by Kleifeld and Chet (28) in the case of the interaction of plant and Trichoderma spp. However, in light of our observations, two quite different reasons may explain why such a correlation between these two types of infections should be excluded. First, endomycorrhizal fungi are not known to undergo a degenerative process during root colonization, as exemplified with $P$. oligandrum (12). Second, the induction of host metabolic changes, culminating in the elaboration of structural barriers at sites of potential Pythium penetration, has never been reported in endomycorrhizal associations (12). Thus, the relationship established between the host plant and $P$. oligandrum appears highly specific, because none of the main events associated with the infection process have been described in compatible interactions involving pathogenic or beneficial microorganisms. The main facets of the altered metabolism induced by $P$. oligandrum concern the abnormal formation of wall appositions beyond the infection sites and the filling of most colonized intercellular spaces with a fibrillo-granular material. The absence of cellulose compounds in these structures, revealed by exoglucanasegold labeling, suggests the deposited products do not originate from the plant cell wall but instead likely correspond to the accumulation of newly formed compounds.

Although the mycoparasitic capabilities of $P$. oligandrum have been abundantly documented $(20,32)$, the possibility that plant disease resistance could be stimulated by this fungus seldom has been raised. Based on the current results, one may speculate that reduction of disease incidence in soils amended with $P$. oligandrum is a multifaceted process that requires the synergistic contribution of several mechanisms, including the induction of plant defense reactions. These results are of particular relevance because they highlight, for the first time, the dual properties of $P$. oligandrum, which in addition to being a strong antagonist in the rhizosphere also is capable of evoking biochemical events characteristic of the natural plant disease resistance process.

When tomato plants were challenged with $F$. oxysporum f. sp. radicis-lycopersici, strong differences in the rate and extent of tissue invasion were observed regardless of whether the roots were previously infected with $P$. oligandrum. Restriction of Fusarium growth to the outermost root tissues together with deposition of newly formed barriers beyond the infection sites were the main visible features of the cellular response to pathogen attack in $P$. oligandrum-inoculated tomato plants. These host reactions appeared to be amplified compared to those seen in nonchallenged, $P$. oligandrum-infected plants. Considering that ingress toward the vascular stele is an essential prerequisite for successful pathogenesis by vascular pathogens (1), enzymatic hydrolysis of the host cell wall components is conceivably one of the most harmful events associated with the infection process by $F$. oxysporum f. sp. radicis-lycopersici (7).

It is not surprising that, in turn, an early process in the expression of plant resistance involves the production of an array of substances for reinforcing cell walls and shielding them from the deleterious action of enzymes and toxins (40). To be efficient, strengthening of host cell walls needs to occur rapidly and in advance of the ingressing fungal hyphae. In recent years, evidence has been provided that the speed and extent to which the plant response to pathogen attack is expressed determines the outcome of a plant-pathogen interaction (31). It has become more and more apparent that stimulation of the plant defense strategy by prior treatments with inducing agents could trigger the host reaction process in such a way that resistance ensues $(5,31)$.

A typical aspect of this induced resistance is shown in the current study, with the formation of structural barriers in the outermost root tissues of tomato plants previously infected with $P$. oligandrum. Support for the close association between root colonization by $P$. oligandrum and induced resistance to $F$. oxysporum f. sp. radicis-lycopersici also came from the observation that intercellular spaces in the epidermis and outer cortex were filled or even occluded by an electron-dense material. If one considers that intercellular spaces are strategic sites for pathogen ingress, it is likely that their occlusion by cementing or toxic substances contributes to the restriction of pathogen spread in inner tissues. Such host reactions were never seen in control roots, where the patterns of Fusarium colonization and host cell alteration were similar in many respects to those known to occur in the tomato- $F$. oxysporum f. sp. radicis-lycopersici interaction (14).

Considerable cellular changes, characterized by the deposition of heterogeneous wall appositions on the inner cell wall surface, were typical features of reaction in epidermal and cortical root cells of Fusarium-infected tomato plants pretreated with P. oligandrum. This phenomenon was amplified by the accumulation of osmiophilic substances in the host cell walls and intercellular spaces of reacting host cells. Considering the functional significance of these cellular changes in restricting pathogen ingress and shielding the inner root tissues from phytotoxic substances, it was essential to determine the nature of these induced barriers. The observation that fungal cells trapped in the dense material accumulating in some intercellular spaces or neighboring wall appositions were often disorganized suggests that the biological function of the newly deposited material was not only mechanical but probably also fungicidal. This assumption was confirmed further by the detection of considerable amounts of phenolic-like substances in these structures.

The high specificity of the labeling patterns obtained with the gold-complexed laccase and $\beta$-1,3-glucanase allowed clear distinction between the distribution of phenolics and $\beta$-1,3-glucans in $P$. oligandrum-colonized tomato root tissues. Interestingly, callose deposition occurred predominantly in the wall appositions, whereas phenolic accumulation appeared to be more widely distributed. Perivascular responses associated with callose deposition have long been reported to be an early event in plant resistance to vascular wilt pathogens (26). Although callose deposition cannot be considered an efficient mechanism for preventing pathogen spread, such a rapid reaction may contribute to the delay of the infection process, allowing sufficient time for the host plant to build up other defense reactions to halt pathogen growth to the outermost root cell layers.

According to their pattern of distribution, phenolic compounds, including phytoalexins, may correspond to the second defensive line involved in the process of sealing-off root tissue, thereby localizing efficiently the pathogen by creating a fungitoxic environment in addition to rendering the plant cell walls impervious to microbial toxins and enzymes. Conceivably, incorporation of phenolics in the host cell walls and wall appositions may result in the elaboration of permeable barriers, preventing pathogen spread and 
enzymatic degradation. Evidence strongly suggests that peroxidasemediated cross-linking of phenolic substances with preexisting wall-bound carbohydrates, such as hemicellulose, pectin, and possibly callose, confers strong rigidity to cell wall structures (22). Thus, it appears likely that deposition of phenolic- or lignin-like compounds is a crucial event in the establishment of effective resistance to $F$. oxysporum f. sp. radicis-lycopersici colonization after treatment with P. oligandrum. Support for this speculation is provided by earlier observations indicating that treatment of carrot cell cultures with oligosaccharides from $P$. aphanidermatum cell walls stimulated the phenylpropanoid pathway, promoting the accumulation of phytoalexins (42).

According to our observations, the defense strategy of tomato plants occurs in two main stages. The first is assumed to involve the rapid accumulation of callose at or beyond the infection sites to slow the growth of the pathogen and to allow the activation of secondary responses that more thoroughly inhibit the pathogen. Such responses associated with the onset of induced resistance include the polymerization and synthesis of phenolic compounds and accumulation of other defense molecules, such as pathogenesisrelated proteins.

Evidence was provided through the use of WGA-ovomucoid-gold complex that chitin in the cell walls of Fusarium hyphae colonizing $P$. oligandrum-infected tomato roots apparently was not altered. The finding that chitin molecules were still present over cell walls of hyphae that had undergone substantial disorganization (Fig. 5D) suggests that production of chitinases is not a primary determinant in the expression of resistance triggered by $P$. oligandrum. It is more likely that toxic substances, such as phenolics and phytoalexins, are the first fungicidal factors, followed by chitinases and other hydrolytic enzymes, such as $\beta-1,3$-glucanases, which probably contribute to the complete disintegration of the fungal cells.

In summary, the current results demonstrate that tomato plants previously inoculated with $P$. oligandrum afford increased resistance to $F$. oxysporum f. sp. radicis-lycopersici attack. This resistance is mainly associated with a strong antagonistic activity in the rhizosphere and in planta as well as with the induction of structural and biochemical barriers that adversely affect pathogen growth and development. These observations provide the first convincing evidence that $P$. oligandrum has the potential to induce plant defense reactions in addition to acting as a mycoparasite.

\section{ACKNOWLEDGMENTS}

This research was supported by grants from the Fonds Québécois pour la formation de chercheurs et l'Aide à la Recherche (FCAR) and the Natural Sciences and Engineering Research Council of Canada (NSERC). We thank S. Noël for excellent technical assistance.

\section{LITERATURE CITED}

1. Beckman, C. H. 1987. The Nature of Wilt Diseases of Plants. The American Phytopathological Society, St. Paul, MN.

2. Bélanger, R. R., Dufour, N., Caron, J., and Benhamou, N. 1995. Chronological events associated with the antagonistic properties of Trichoderma harzianum against Botrytis cinerea: Indirect evidence for sequential role of antibiosis and parasitism. Biocontrol Sci. Technol. 5:41-53.

3. Benhamou, N. 1989. Preparation and applications of lectin-gold complexes. Pages 95-143 in: Colloidal Gold, Principles, Methods and Applications. Vol. 1. M. A. Hayat, ed. Academic Press, New York.

4. Benhamou, N. 1992. Ultrastructural detection of $\beta$-1,3-glucans in tobacco root tissues infected by Phytophthora parasitica var. nicotianae using a gold-complexed tobacco $\beta$-1,3-glucanase. Physiol. Mol. Plant Pathol. 41:351-370.

5. Benhamou, N. 1995. Elicitor-induced resistance in tomato plants against fungal pathogens: Ultrastructure and cytochemistry of the induced response. Scanning Microsc. 9:861-880.

6. Benhamou, N., Chamberland, H., Ouellette, G. B., and Pauzé, F. J. 1987. Ultrastructural localization of $\beta-1,4-D-g l u c a n s$ in two pathogenic fungi and in their host tissues by means of an exoglucanase-gold complex. Can.
J. Microbiol. 33:405-417.

7. Benhamou, N., Chamberland, H., and Pauzé, F. J. 1990. Implication of pectic components in cell surface interactions between tomato root cells and Fusarium oxysporum f. sp. radicis-lycopersici: A cytochemical study by means of a lectin with polygalacturonic-acid binding specificity. Plant Physiol. 92:995-1003.

8. Benhamou, N., Lafontaine, P. J., and Nicole, M. 1994. Induction of systemic resistance to Fusarium crown and root rot in tomato plants by seed treatment with chitosan. Phytopathology 84:1432-1444.

9. Benhamou, N., and Thériault, G. 1992. Treatment with chitosan enhances resistance of tomato plants to the crown and root rot pathogen Fusarium oxysporum f. sp. radicis-lycopersici. Physiol. Mol. Plant Pathol. 41: 33-52.

10. Berry, L. A., Jones, E. E., and Deacon, J. W. 1993. Interaction of the mycoparasite Pythium oligandrum with other Pythium species. Biocontrol Sci. Technol. 3:247-260.

11. Boland, G. J. 1990. Biological control of plant diseases with fungal antagonists: Challenges and opportunities. Can. J. Plant Pathol. 12:295-299.

12. Bonfante-Fasolo, P., and Perotto, S. 1992. Plants and endomycorrhizal fungi: The cellular and molecular basis of their interaction. Pages 445470 in: Molecular Signals in Plant-Microbe Communications. D. P. S. Verma, ed. CRC Press, New York.

13. Bradshaw-Smith, R. P., Whalley, W. M., and Craig, G. D. 1991. Interactions between Pythium oligandrum and the fungal foot rot of peas. Mycol. Res. 95:861-865.

14. Charest, P. M., Ouellette, G. B., and Pauzé, F. J. 1984. Cytological observations of the early infection process of Fusarium oxysporum f. sp. radicis-lycopersici . Can. J. Bot. 62:1232-1244.

15. Chérif, M., and Benhamou, N. 1990. Cytochemical aspects of chitin breakdown during the parasitic action of a Trichoderma sp. on Fusarium oxysporum f. sp. radicis-lycopersici. Phytopathology 80:1406-1414.

16. Chérif, M., Benhamou, N., and Bélanger, R. R. 1991. Ultrastructural and cytochemical studies of fungal development and host reactions in cucumber plants infected by Pythium ultimum. Physiol. Mol. Plant Pathol. 39:353-375.

17. Chet, I. 1987. Trichoderma: Application, mode of action, and potential as a biocontrol agent of soil-borne plant pathogenic fungi. Pages 137160 in: Innovative Approaches to Plant Disease Control. I. Chet, ed. John Wiley \&Sons, New York.

18. Drechsler, C. 1943. Antagonism and parasitism among some oomycetes associated with root rot. J. Wash. Sci. Acad. 33:21-28.

19. Elad, Y., Lifshitz, R., and Baker, R. 1985. Enzymatic activity of the mycoparasite Pythium nunn during interaction with host and non-host fungi. Physiol. Plant Pathol. 27:131-148.

20. Foley, M. F., and Deacon, J. W. 1986. Susceptibility of Pythium species and other fungi to antagonism by the mycoparasite Pythium oligandrum. Soil Biol. Biochem. 18:91-95.

21. Frens, G. 1973. Controlled nucleation for regulation of the particle size in monodisperse gold solutions. Nature Physical Sci. 241:20-22.

22. Fry, S. C. 1986. Polymer-bound phenols as natural substrates of peroxidases. Pages 169-182 in: Molecular and Physiological Aspects of Plant Peroxidase. H. Greppin, C. Penel, and Th. Gaspar, eds. Université de Genève, Switzerland.

23. Geiger, J. P., Rio, B., Nandris, D., and Nicole, M. 1986. Laccases of Rigidoporus lignosus and Phellinus noxius: 1. Purification and some physicochemical properties. Appl. Biochem. Biotechnol. 12:121-133.

24. Jarvis, W. R. 1989. Fusarium crown and root rot of tomatoes. Phytoprotection 69:49-64.

25. Jarvis, W. R. 1989 Allelopathic control of Fusarium oxysporum f. sp. radicis-lycopersici. Pages 479-486 in: Vascular Wilt Diseases of Plants. E. C. Tjamos and C. Beckman, eds. NATO ASI Series. Vol. H28. SpringerVerlag, Berlin.

26. Jordan, C. M., Endo, R. M., and Jordan, L. S. 1987. Penetration and colonization of resistant and susceptible Apium graveolens by Fusarium oxysporum f. sp. apii race 2: Callose as a structural response. Can. J. Bot. 66:2385-2391.

27. Klecan, A. L., Hippe, S., and Lumsden, R. D. 1990. Reduced growth of Erysiphe graminis f. sp. hordei induced by Tilletiopsis pallescens. Phytopathology 80:325-331.

28. Kleifeld, O., and Chet, I. 1992. Trichoderma harzianum-Interaction with plants and effect on growth response. Plant Soil 144:267-272.

29. Kloepper, J. W. 1993. Plant growth-promoting rhizobacteria as biological control agents. Pages 255-274 in: Soil Microbial Technologies. B. Metting, ed. Marcel Dekker, Inc., New York.

30. Kratka, J., Bergmanova, E., and Kudelova, A. 1994. Effect of Pythium oligandrum on biochemical changes in cucumber (Cucumis sativus L.). J. Plant Dis. Prot. 101:406-413.

31. Kuć, J. 1987 Plant immunization and its applicability for disease control. Pages 255-274 in: Innovative Approaches to Plant Disease Control. I. 
Chet, ed. John Wiley \& Sons, New York.

32. Laing, S. A. K., and Deacon, J. W. 1990. Video microscopical comparison of mycoparasitism by Pythium oligandrum, Pythium nunn, and an unnamed Pythium species. Mycol. Res. 95:469-479.

33. Lemanceau, P., and Alabouvette, C. 1993. Suppression of Fusarium wilts by fluorescent pseudomonads: Mechanisms and applications. Biocontrol Sci. Technol. 3:219-234.

34. Lewis, K., Whipps, J. M., and Cooke, R. C. 1989. Mechanisms of biological disease control with special reference to the case study of Pythium oligandrum as an antagonist. Pages 191-217 in: Biotechnology of Fungi for Improving Plant Growth. J. M. Whipps and R. D. Lumdsen, eds. Cambridge University Press, Cambridge.

35. Lutchmeah, R. S., and Cooke, R. C. 1984. Aspects of antagonism by the mycoparasite Pythium oligandrum. Trans. Br. Mycol. Soc. 83:696-700.

36. Martin, F. N., and Hancock, J. G. 1987. The use of Pythium oligandrum for biological control of preemergence damping-off caused by $P$. ultimum. Phytopathology 77:1013-1020.

37. Mcquilken, M. P., Whipps, J. M., and Cooke, R. C. 1990. Control of damping-off in cress and sugar beet by commercial seed coating with Pythium oligandrum. Plant Pathol. 39:452-462.

38. Rey, P., Benhamou, N., and Tirilly, Y. Ultrastructural and cytochemical studies of cucumber roots infected by two Pythium species with different modes of pathogenicity. Physiol. Mol. Plant Pathol. In press.

39. Ribeiro, W. R. C., and Butler, E. E. 1992. Isolation of mycoparasitic species of Pythium with spiny oogonia from soil in California. Mycol. Res. 99:963-969.

40. Ride, J. P. 1983. Cell wall and other structural barriers in defense. Pages 215-235 in: Biochemical Plant Pathology. J. A. Callow, ed. John Wiley \& Sons, New York.

41. Rowe, R. C., and Farley, J. D. 1981. Strategies for controlling Fusarium crown and root rot in greenhouse tomatoes. Plant Dis. 65:107-112.

42. Schnitzler, J. P., and Seitz, H. U. 1989. Rapid responses of cultured carrot cells and protoplasts to an elicitor from the cell wall of Pythium aphanidermatum (Edson) Fitzp. Z. Naturforsh. 44:1020-1028.

43. Sivan, A., and Chet, I. 1987. Biological control of Fusarium crown and root rot of tomato by Trichoderma harzianum under field conditions. Plant Dis. 71:587-592.

44. Vaartaja, O. 1968. Pythium and Mortierella in soils of Ontario forest nurseries. Can. J. Microbiol. 14:265-269.

45. Vesely, D. 1987. Biological control of damping-off pathogens by treating sugar-beet with a powdery preparation of the Pythium oligandrum mycoparasite in large-scale field trials. Pages 445-449 in: Interrelationship Between Microorganisms and Plants in Soil. V. Vancura and F. Kunc, eds. Czechoslovak Academy of Sciences, Liblice. 